\title{
THE EFFECT OF CHLORPYRIFOS UPON ATPase ACTIVITY OF SARCOPLASMIC RETICULUM AND BIOMECHANICS OF SKELETAL MUSCLE CONTRACTION
}

\author{
D. M. NOZDRENKO, M. S. MIROSHNYCHENKO, V. M. SOROCA, \\ L. V. KORCHINSKA, D. O. ZAVODOVSKIY \\ Educational and Scientific Centre Institute of Biology, \\ Taras Shevchenko National University of Kyiv, Ukraine; \\ e-mail:ddd@univ.kiev.ua
}

\begin{abstract}
We investigated the effect of chlorpyrifos, an organophosphate insecticide, on $\mathrm{Ca}^{2+}, \mathrm{Mg}^{2+}$-ATPase activity of sarcoplasmic reticulum and on contraction dynamics (force and length changes) of Rana temporaria m. tibialis anterior muscle fiber bundles. All of the used concentrations of chlorpyrifos $\left(10^{-6}\right.$ to $\left.10^{-5} \mathrm{M}\right)$ caused decrease of $\mathrm{Ca}^{2+}, \mathrm{Mg}^{2+}$-ATPase activity. The inhibition of $\mathrm{Ca}^{2+}, \mathrm{Mg}^{2+}$-ATPase activity by chlorpyriphos in concentrations of $10^{-6} \mathrm{M}$ to $7.5 \cdot 10^{-6} \mathrm{M}$ is due to permeation of sarcoplasmic reticulum rather than due to direct enzyme inhibition by organophosphate insecticides. The inhibitory properties of the compound were higher at increased concentration and exposure timeframes. Chlorpyrifos in concentration range of $10^{-6}$ to $7.5 \cdot 10^{-6} M$ causes changes in muscle fiber response force that were more pronounced than changes in contractile length. We demonstrated inhibition of $\mathrm{Ca}^{2+}, \mathrm{Mg}^{2+}$-ATPase activity caused by noncholinergic effects of chlorpyriphos. It is possible to conclude that influence of organophosphate insecticides happens not only in the neuromuscular transmission but also on the level of subcellular structures.
\end{abstract}

Key words: chlorpyrifos, ATPase activity of sarcoplasmic reticulum, muscle contraction.

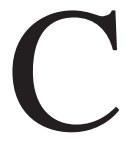

hlorpyriphos (O,O-diethyl O-3,5,6-trichloropyridin-2-yl phosphorothioate) is an organophosphate insecticide (OPI) widely used in household, agricultural and industrial applications in over 100 countries in the last 40 years. OPI may enter organism via dermal, oral or respiratory pathways and cause poisoning affecting neuromuscular signal exchange resulting in skeletal muscle pathologies [1-4].

There is as yet no universally accepted theory of mechanism of pathological changes that cause damage to muscle functioning under effects of OPI and other anthropogenic factors [5-8]. The toxicity of organophosphate insecticides is explained by irreversible inhibition of acetylcholine esterase leading to acetylcholine accumulation and excessive activation of cholinergic receptors $[9,10]$.

Generally, the research of OPI's effects on muscle contraction is centered on endpoint change in muscle strength, and the dynamic developments in these processes remain unstudied. The equilibrium stable state of muscle contraction under effect of external substances may vary within wide margins due to differences in concentrations and timeframes
$[7,11,12]$, which makes it difficult to give adequate interpretations to the results. Thus, we paid special attention to periods it takes muscle to reach equilibrium stable state of contraction under effect of the investigated chlorpyriphos compound.

The kinetics and dynamics of OPI poisoning is known to depend not only on different dosage, but also on elimination half-life of OPI [8, 9, 11, 12, 16]. The calculations of effects' duration upon organism or a particular organ are complicated due to variations in elimination time.

Studies of properties of particular muscles in living organism are difficult to perform, as measurements of mechanical kinetic muscle properties are tied to their changes due to efferent and humoral regulatory effects and fatigue [15]. The contractile processes in poikilotherms are known to be slower than in homoiotherms, which make a number of research objectives required for the correct registration of dynamic parameters of muscle contraction easier to achieve. Therefore, we chose muscle fiber bundles from m. tibialis anterior of Rana temporaria as experimental subjects. 
The aim of this study was to establish the concentrational variations of chlorpyriphos' effects on ATPase activity of sarcoplasmic reticulum (SR) and biomechanical contractile properties of skeletal muscle (SM), and to analyze the progression of these changes over time depending on concentrations of the compound.

\section{Materials and Methods}

The contractile force of SM fiber bundles of $\mathrm{m}$. tibialis anterior muscle fibers from a hind leg of Rana temporaria frog was determined with a tensometer device [11, 12].

$\mathrm{Ca}^{2+}, \mathrm{Mg}^{2+}$-ATPase activity of SR was determined by Fiske and Subbarow method [13]. Protein concentration was determined by Bradford assay [14].

The experiments were done in accordance with guidelines for keeping and work with laboratory animals laid down in the 'European convention for the protection of vertebrate animals used for experimental and other scientific purposes' (Strasbourg, 1986).

The statistical analysis of data was done with variation statistics methods in Origin 7.0 software, using Student's $t$-test. The differences between test and control samples were considered significant at $P \leq 0.05$.

\section{Results and Discussion}

The experimental data obtained demonstrates inhibition of $\mathrm{Ca}^{2+}, \mathrm{Mg}^{2+}$-ATPase activity of SR under effect of chlorpyriphos in concentrations $10^{-6}$ to $10^{-5} \mathrm{M}$ (Table 1). Decreased $\mathrm{Ca}^{2+}, \mathrm{Mg}^{2+}$-ATPase activity may result from permeation of SR membrane due to intensive lipid peroxidation [17]. It may be explained by the capacity of these substances to enter cell through the plasma membrane and disrupt intracellular processes. According to our results, the possible molecular mechanisms underlying chlorpyriphos toxicity include inhibition of SR $\mathrm{Ca}^{2+}, \mathrm{Mg}^{2+}-$
ATPase activity and unbalancing of intracellular $\mathrm{Ca}^{2+}$ homeostasis.

Changes in activity of ATPases under influence of OPI may be an important factor in cellular dysfunctions due to disruptions in transmembrane cation exchange [17, 19]. The authors [19] demonstrated inhibition of $\mathrm{Ca}^{2+}, \mathrm{Mg}^{2+}$-ATPase and $\mathrm{Na}, \mathrm{K}-$ ATPase activity of sarcolemma and of protein kinase A (cAMP-dependent protein kinase) under effect of OPI as potential biological mechanism inhibiting neuromuscular impulse exchange. It has been also demonstrated that decreased $\mathrm{Ca}^{2+}, \mathrm{Mg}^{2+}$-ATPase activity may result from damaged SR membrane and not from direct OPI effect on the enzyme [20].

It is therefore sensible to assume that one of the factors of complex OPI effect on skeletal muscle function is the inhibition of SR $\mathrm{Ca}^{2+}, \mathrm{Mg}^{2+}$-ATPase activity, which results in decreased contractility of the muscle, as described in [21]. One of the important changes happening in muscle fibers in fatigue is increased $\mathrm{Ca}^{2+}$ concentration caused due to decreased uptake of this ion by SR [22].

Our results demonstrate that chlorpyriphos causes significant changes to contractile parameters of muscle fibers in concentrations of $10^{-6}$ to $10^{-5} \mathrm{M}$ (Fig. 1). The compound had no significant effect on contractile properties of muscle fibers in concentrations below $10^{-6} \mathrm{M}$. Chlorpyriphos introduced into incubation medium in concentrations above $10^{-5} \mathrm{M}$ caused total arrest of muscle fiber contractions within 12 min of the experiment; consequently, we considered investigation of its effect in such concentrations impractical.

Chlorpyriphos introduction into incubation medium in concentration of $10^{-6} \mathrm{M}$ caused uniform decrease in contractile parameters of SM for the entire duration of stimulus. The maximum inhibition of muscle productivity was observed starting from $21^{\text {st }}$ min of the experiment and was $82.8 \pm 1.9 \%$ of control (Fig. 1, $A$ ). Changes in muscle length were

Ta b le 1. The effect of chlorpyrifos solutions on $\mathrm{Ca}^{2+}, \mathrm{Mg}^{2+}$-ATPase activity of SR from $\mathrm{m}$. tibialis anterior muscle fibers of Rana temporaria $(M \pm m, n=10)$

\begin{tabular}{l|c|c|c|c|c|c}
\hline \multirow{2}{*}{ Enzyme } & \multicolumn{5}{|c}{ Chlorpyriphos concentration, M } \\
\cline { 2 - 6 } & Control & $10^{-6}$ & $2.5 \cdot 10^{-6}$ & $7.5 \cdot 10^{-6}$ & $5 \cdot 10^{-6}$ & $10^{-5}$ \\
\hline $\begin{array}{l}\mathrm{Ca}^{2+}, \mathrm{Mg}^{2+} \text {-ATPase } \\
\begin{array}{l}\text { activity, nM of } \mathrm{P}_{\mathrm{i}} \times \\
\times \mathrm{min}^{-1} \times \mathrm{mg} \text { of protein }\end{array}\end{array}$ & $246.8 \pm 1.5$ & $234.6 \pm 1.2^{*}$ & $211.3 \pm 2.5^{*}$ & $203.3 \pm 1.9^{*}$ & $193.5 \pm 2.1^{*}$ & $186.5 \pm 2.1^{*}$ \\
\hline
\end{tabular}



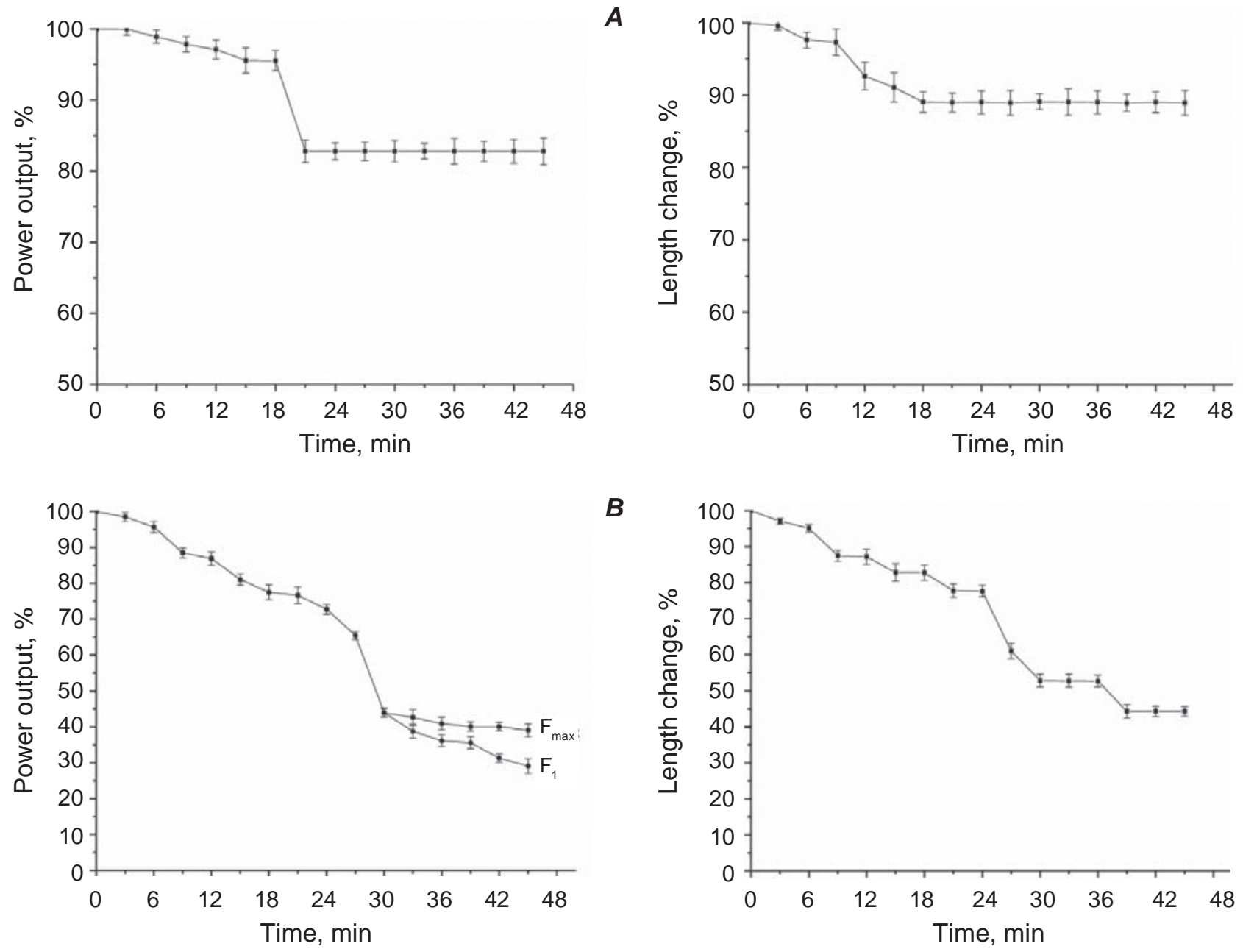

B

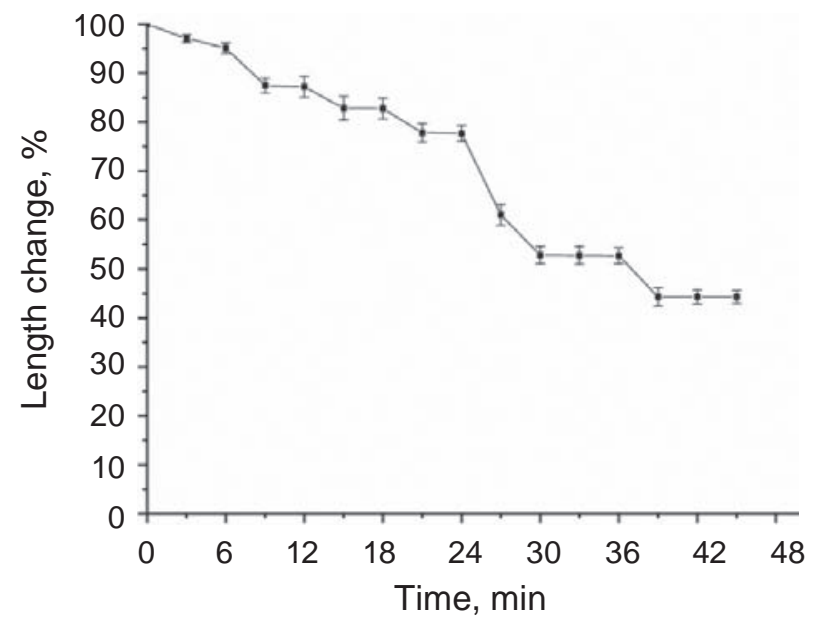

Fig. 1. The effect of chlorpyriphos in concentrations of $10^{-6} \mathrm{M}(\mathrm{A})$ and $2.5 \cdot 10^{-6} \mathrm{M}(\mathrm{B})$ upon dynamic contraction properties of $m$. tibialis anterior as function of exposure time $(M \pm m, n=10) . F_{\max }$ denotes maximum power output; $F_{1}$ denotes changes in SM fiber strength at level corresponding to equilibrium stable state

less pronounced and constituted $89.0 \pm 1.7 \%$ of control.

Chlorpyriphos in concentration of $2.5 \cdot 10^{-6}$ resulted in significantly more pronounced inhibition of SM contraction activity (Fig. 1, B). The maximum strength decrease is denoted as $\mathrm{F}_{\max }$ (Fig. $1, B$ ) and constituted $39.0 \pm 1.8 \%$ on the increase stage after 30 min incubation with chlorpyriphos, and denoted as $\mathrm{F}_{1}$ in equilibrium stable state, in which the decrease was $29.1 \pm 2.1 \%$ from control values.

Length changes under effect of chlorpyriphos $\left(2.5 \cdot 10^{-6} \mathrm{M}\right)$ were less pronounced than changes in power output. The maximum inhibition was $44.3 \pm 1.3 \%$ of control values beginning on $39^{\text {th }} \mathrm{min}$ of the experiment. It must be noted that the length of muscle changed uniformly for the entire duration of the stimulus.
There were no marked changes in dynamic parameters for chlorpyriphos concentration of $5 \cdot 10^{-6} \mathrm{M}$ in comparison to the effects of the compound in concentration of $2.5 \cdot 10^{-6} \mathrm{M}$. Nevertheless, we observed noticeable fluctuations in strength of response to stimulus. The muscle fibers were unable to maintain a uniform strength of response after $30^{\text {th }}$ min of the experiment. The maximum inhibition of power output was $38.9 \pm 1.8 \%$ and was detected on the $45^{\text {th }}$ min of the experiment (Fig. 2, $A$ ). The maximum decrease in contraction length was found on $54^{\text {th }} \mathrm{min}$ of incubation, and constituted $40.3 \pm 2.1 \%$ from that of control.

The effect of chlorpyriphos in concentration of $7.5 \cdot 10^{-6}$ caused maximum inhibition of SM fibers power output after $30^{\text {th }}$ min of exposure (Fig 2, B). The contraction strength was at $20.0 \pm 2.3 \%$ of that 

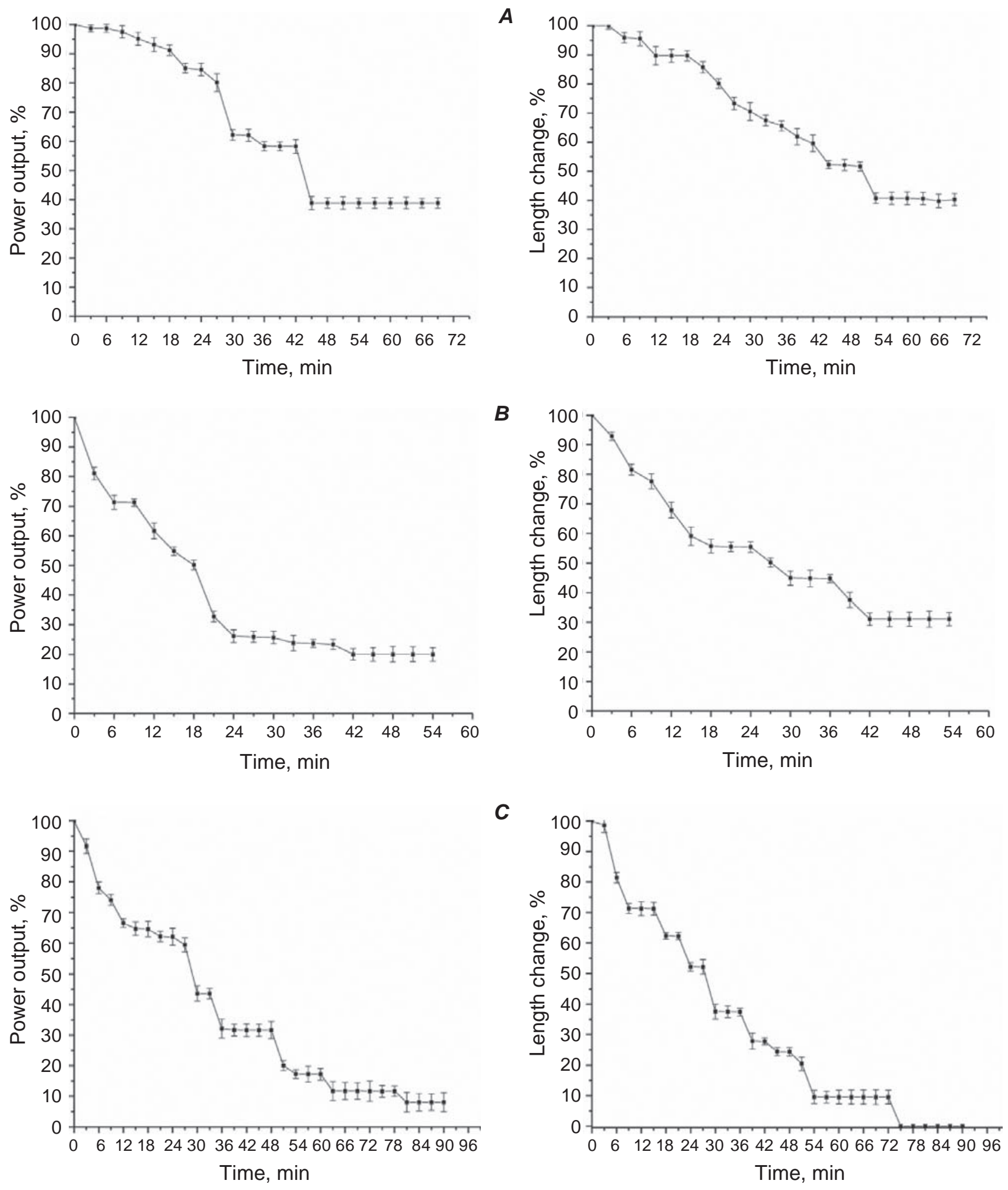

Fig. 2. The effect of chlorpyriphos in concentrations of $5 \cdot 10^{-6} \mathrm{M}(\mathrm{A}), 7.5 \cdot 10^{-6}(\mathrm{~B})$, and $10^{-5} \mathrm{M}(\mathrm{C})$ upon dynamic contraction properties of $m$. tibialis anterior as function of exposure time $(M \pm m, n=10)$

of control. The inhibitive effect of chlorpyriphos on muscle power output was observed immediately after addition of the compound to incubation buffer.
The power output level decreased by $20 \%$ in comparison to control within three min of the beginning of exposure, and the corresponding decrease in con- 
traction length was detected beginning on $6^{\text {th }}$ min the maximum decrease in contraction length was $31.0 \pm 2.2 \%$ from the control values. The decrease in contraction length reached stable level on $42^{\text {nd }}$ min of the exposure to chlorpyriphos. Therefore, this dynamic parameter is less sensitive to inhibitive effects of chlorpyriphos in concentration of $7.5 \cdot 10^{-6} \mathrm{M}$ than contraction strength.

Chlorpyriphos in concentrations of $10^{-5} \mathrm{M}$ caused nearly total inhibition of muscle contractile activity. The maximum decrease in contraction strength was observed after $63^{\text {rd }}$ min of chlorpyriphos exposure and was $8.1 \pm 3.1 \%$ from that of control (Fig. 2, C).

There was no detectable change in muscle length during contractions under chlorpyriphos exposure after $75^{\text {th }}$ min of the experiment.

Therefore, these results demonstrate concentration-dependent effect of chlorpyriphos upon muscle contraction dynamics. It should be noted that muscle power output changed more noticeably under exposure to chlorpyriphos in concentrations of $10^{-6}$ to $7.5 \cdot 10^{-6}$ than muscle contraction length (Fig. 3).

The contractile length of muscle under chlorpyriphos exposure in concentration of $10^{-5} \mathrm{M}$ was undetectable, and the muscle power output was no higher than $10 \%$ of that of control. On the other hand, the differences between contraction strength inhibition and changes in contraction length were not significant only in under effects of chlorpyriphos in concentration of $5 \cdot 10^{-6} \mathrm{M}$ (Fig. 3).

We interpret the experimental data as demonstrating the marked inhibition in dynamic parameters of SM fibers contraction due to noncholinergic effects of chlorpyriphos. Muscle's inability to maintain stable contraction strength under tetanic contraction indicates not only the variability in effects of different chlorpyriphos concentrations upon contractile activity, but also differences in molecular mechanisms of generation of response strength and in propagation of dynamic muscle movements [6, 22-25]. The observed decrease in dynamic parameters of contraction results probably from direct influence of chlorpyriphos on myofilaments unmediated by acetylcholine esterase. These results allow us to propose a mechanism of decrease in muscle contractile function under OPI exposure that is independent of their cholinergic effect. This is in accordance with results [26], which show that under low doses of OPI changes in SM are observable despite nearly no detectable decrease in acetylcholine

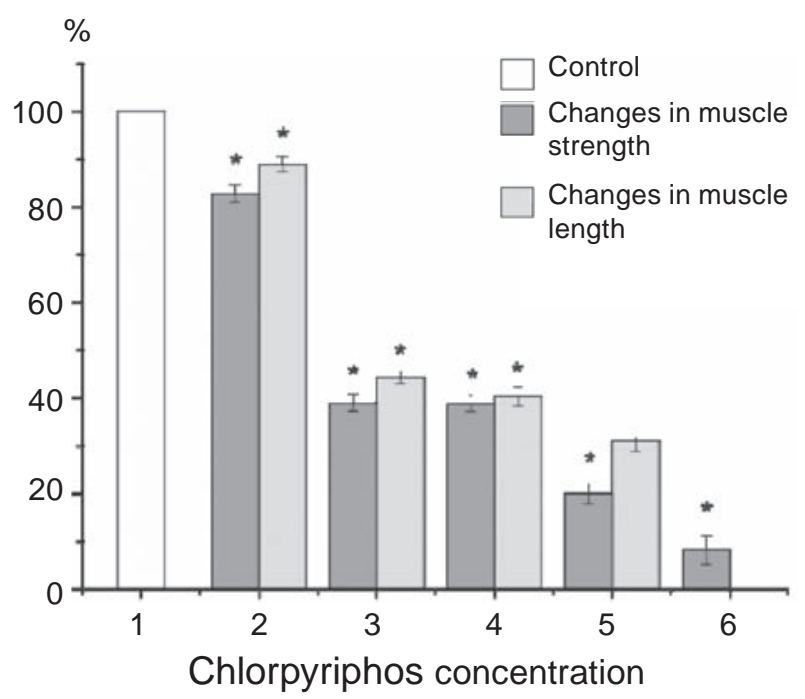

Fig. 3. Maximum decrease in dynamic parameters of contraction of $m$. tibialis anterior under stimulus (30 Hz $3000 \mathrm{~ms}$ pulse) and chlorpyriphos exposure. 1 - control, 2 to 6 - chlorpyriphos concentrations $10^{-6} ; 2.5 \cdot 10^{-6} ; 5 \cdot 10^{-6} ; 7.5 \cdot 10^{-6} ; 10^{-5} \mathrm{M}$, correspondingly $(M \pm m, n=10) ; *$ denotes changes significant with $P<0.05$ in comparison to control

esterase activity. The demonstrated inhibition of SR $\mathrm{Ca}^{2+}, \mathrm{Mg}^{2+}$-ATPase activity and dynamic contraction properties of $\mathrm{m}$. tibialis anterior from Rana temporaria due to noncholinergic effects of chlorpyriphos indicates that disruptions in SM function under OPI exposure happens not just in the neurotransmission, but on cellular and subcellular levels as well.

\section{ВПЛИВ ХЛОРПІРИФОСУ НА АКТИВНІСТЬ АТРази САРКОПЛАЗМАТИЧНОГО РЕТИКУЛУМА ТА БІОМЕХАНІКУ СКОРОЧЕННЯ СКЕЛЕТНИХ М'ЯЗІВ}

\section{Д. М. Ноздренко, М. С. Мірошниченко, \\ В. М. Сорока, Л. В. Корчинська, \\ Д. О. Заводовський}

ННЦ «Інститут біології», Київський національний університет імені Тараса Шевченка, Україна; e-mail: ddd@univ.kiev.ua

Вивчали вплив фосфорорганічного інсектициду - хлорпірифосу - на активність $\mathrm{Ca}^{2+}, \mathrm{Mg}^{2+}$-АТРази саркоплазматичного ретикулума (СР) і на біомеханіку скорочення скелетних м'язів (m. tibialis anterior) жаби Rana temporaria. Показано, що активність $\mathrm{Ca}^{2+}, \mathrm{Mg}^{2+}$-АТРази СР 
пригнічувалась хлорпірифосом у діапазоні концентрацій від $10^{-6}$ до $10^{-5}$ М. Активність $\mathrm{Ca}^{2+}, \mathrm{Mg}^{2+}$-АТРази знижувалась у діапазоні від $10^{-6}$ до 7,5·10-6 M найімовірніше внаслідок порушення цілісності мембрани СР. Показано, що інгібіторні властивості хлорпірифосу посилювалися як за підвищення концентрацій, так і у разі збільшення тривалості його дії. У концентраціях від $10^{-6}$ до 7,5·10-6 М хлорпірифос змінював силову відповідь м'язових волокон вираженіше порівняно зі зміною довжини скорочення. Встановлено пригнічення $\mathrm{Ca}^{2+}, \mathrm{Mg}^{2+}-$ АТРази СР внаслідок нехолінергічних ефектів дії хлорпірифосу.

К л юч о в і с л о в а: хлорпірифос, АТРазна активність саркоплазматичного ретикулума, м'язове скорочення.

\section{ВЛИЯНИЕ ХЛОРПИРИФОСА НА АКТИВНОСТЬ АТРазы САРКОПЛАЗМАТИЧЕСКОГО РЕТИКУЛУМА И БИОМЕХАНИКУ СОКРАЩЕНИЯ СКЕЛЕТНЫХ МЫШЦ}

\author{
Д. Н. Ноздренко, Н. С. Мирошниченко, \\ В. М. Сорока, Л. В. Корчинская, \\ Д. А. Заводовский

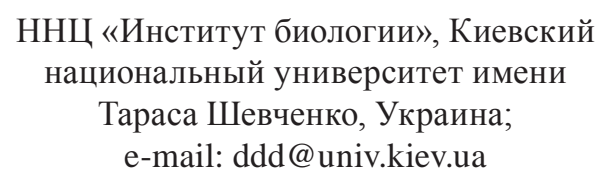

Исследовали влияние фосфорорганического инсектицида - хлорпирифоса - на активность $\mathrm{Ca}^{2+}, \mathrm{Mg}^{2+}$-АТРазы саркоплазматического ретикулума (СР) и на биомеханику сокращения скелетных мышц (m. tibialis anterior) жабы Rana temporaria. Показано, что активность $\mathrm{Ca}^{2+}, \mathrm{Mg}^{2+}-$ АТРазы СР угнеталась хлорпирифосом в диапазоне концентраций от $10^{-6}$ до $10^{-5} \mathrm{M}$. Активность $\mathrm{Ca}^{2+}, \mathrm{Mg}^{2+}$-АТРазы снижалась в диапазоне концентраций от $10^{-6}$ до $7,5 \cdot 10^{-6} \mathrm{M}$ вероятнее всего в результате нарушения целостности мембраны СР. Показано, что ингибиторные свойства хлорпирифоса усиливались как при повышении концентраций, так и при увеличении продолжительности его действия. В концентрациях от $10^{-6}$ до 7,5·10-6 М хлорпирифос изменяет силовой ответ мышечных волокон более выражено по сравнению с изменением длины сокращения. Установлено угнетение $\mathrm{Ca}^{2+}, \mathrm{Mg}^{2+}$-АТРазы сар- коплазматического ретикулума в результате нехолинергических эффектов воздействия хлорпирифоса.

К лючевы е с с о в а: хлорпирифос, АТРазная активность саркоплазматического ретикулума, мышечное сокращение.

\section{References}

1. Reiner E, Radić Z, Simeon-Rudolf V. Mechanisms of organophosphate toxicity and detoxication with emphasis on studies in Croatia. Arh Hig Rada Toksikol. 2007; 58(3): 329-338.

2. Marrs TC. Toxicology of insecticides to mammals. Pest Manag Sci. 2012; 68(10): 13321336.

3. Yang CC, Deng JF. Intermediate syndrome following organophosphate insecticide poisoning. J Chin Med Assoc. 2007; 70(11): 467-472.

4. Abdou H. M., El Mazoudy R. H. Myotoxic and hyperlipidemic effects of diazinon in female rats. J Med Res Inst. 2007; 28(3): 292-298.

5. Abdou HM, ElMazoudy RH. Oxidative damage, hyperlipidemia and histological alterations of cardiac and skeletal muscles induced by different doses of diazinon in female rats. J Hazard Mater. 2010; 182(1-3): 273-278.

6. Nozdrenko D, Prylutskyy Yu, Ritter U, Scharff P. Protective effect of water-soluble pristine $C_{60}$ fullerene in ischemia-reperfusion injury of skeletal muscle. Int J Phys Pathophys. 2014; 5(2): 97-110.

7. Nozdrenko DN, Bogutska KI. About molecular mechanisms of fiber muscle contraction at transition to new equilibrium state: Analysis of experimental data using three-componential electrical stimulating signal. Biopolym Cell. 2005; 21(3): 283-286.

8. Bohuts'ka KI, Pryluts'kyy IuI, Nozdrenko DM. The use of aluminum and its compounds for the biomedical purposes. Fiziol Zh. 2014; 60(1): 9197. (In Ukrainian).

9. Bajgar J. Non-cholinergic effects of organophosphates. Cas Lek Cesk. 1993; 132(17): 513-517.

10. Bajgar J, Kuca K, Jun D, Bartosova L, Fusek J. Cholinesterase reactivators: the fate and effects in the organism poisoned with organophosphates/ nerve agents. Curr Drug Metab. 2007; 8(8): 803809. 
11. Nozdrenko DM, Korchinska LV, Soroca VM. Activity of $\mathrm{Ca}^{2+}, \mathrm{Mg}^{2+}$-ATPase of sarcoplasmic reticulum and contraction strength of the frog skeletal muscles under the effect of organophosphorus insecticides. Ukr Biochem $J$. 2015; 87(4): 63-69. (In Ukrainian).

12. Khoma OM, Zavodovs'ky DA, Nozdrenko DN, Dolhopolov OV, Miroshnychenko MS, Motuziuk OP. Dynamics of ischemic skeletal soleus muscle contraction in rats. Fiziol Zh. 2014; 60(1): 34-40. (In Ukrainian).

13. Fiske CH, Subbarow Y. Phosphorus compounds of muscle and liver. Science. 1929; 70(1816): 381382.

14. Bradford MM. A rapid and sensitive method for the quantitation of microgram quantities of protein utilizing the principle of protein-dye binding. Anal Biochem. 1976; 72: 248-254.

15. Nozdrenko DN, Shut AN, Prylutskyy YI. The possible molecular mechanism of the nonlinearity muscle contraction and its experimental substantiation. Biopolym Cell. 2005; 21(1): 80-83.

16. Nozdrenko DM, Bogutska KI, Prylutskyy YI, Korolovych VF, Evstigneev MP, Ritter U, Scharff $\mathrm{P}$. Impact of $\mathrm{C}_{60}$ fullerene on the dynamics of force-speed changes in soleus muscle of rat at ischemia-reperfusion injury. Fiziol Zh. 2015;61(2):48-59.

17. Mehta A, Verma RS, Srivastava N. Chlorpyrifos-induced alterations in rat brain acetylcholinesterase, lipid peroxidation and ATPases. Indian J Biochem Biophys. 2005; 42(1): 54-58.

18. Hazarika A, Sarkar SN, Hajare S, Kataria M, Malik JK. Influence of malathion pretreatment on the toxicity of anilofos in male rats: a biochemical interaction study. Toxicology. 2003; 185(1-2): 1-8.
19. Xiao C, He FS, Li QS, Niu Y, Yu T. Potential biochemical mechanisms of neuromuscular junction transmission dysfunction induced by organophosphorus insecticides. Zhonghua Lao Dong Wei Sheng Zhi Ye Bing Za Zhi. 2003; 21(3): 191-193.

20. Barber D, Hunt J, Ehrich M. Inhibition of calcium-stimulated ATPase in the hen brain P2 synaptosomal fraction by organophosphorus esters: relevance to delayed neuropathy. $J$ Toxicol Environ Health A. 2001; 63(2): 101-113.

21. Nozdrenko DM, Abramchuk OM, Soroca VM, Miroshnichenko NS. Aluminum chloride effect on $\mathrm{Ca}^{2+}, \mathrm{Mg}^{2+}$-ATPase activity and dynamic parameters of skeletal muscle contraction. $U k r$ Biochem J. 2015; 87(5): 38-45.

22. Allen DG, Lamb GD, Westerblad H. Skeletal muscle fatigue: cellular mechanisms. Physiol Rev. 2008; 88(1): 287-332.

23. Bohutska KI, Tsymbalyuk OV, Danylova VM, Miroshnychenko MS. Effect of $\mathrm{pH}$ on ATPase myosin activity of different muscle types. Fiziol Zh. 2003; 49(6): 52-55.

24. Miroshnichenko NS, Balanuk IV, Nozdrenko DN. Packing of myosin molecules in muscle thick filaments. Cell Biol Int. 2000; 24(6): 327-333.

25. Nozdrenko DM, Abramchuk OM, Soroca VM, Miroshnichenko NS. The effect of the aluminum chloride - quercetin complex on $\mathrm{Ca}^{2+}, \mathrm{Mg}^{2+}$ ATPase activity and contraction dynamic properties of muscle tibialis anterior from Rana temporaria. Ukr Biochem J. 2015; 87(6): 76-85.

26. Yang ZP, Dettbarn WD. Lipid peroxidation and changes in cytochrome c oxidase and xanthine oxidase activity in organophosphorous anticholinesterase induced myopathy. J Physiol Paris. 1998; 92(3-4): 157-161.

Received 27.10.2015 